\title{
"Theory of Revolution" in the thought of Allameh Sadr
}

\author{
Mohammad Hossein Jamshidi ${ }^{1} \&$ Samira Nasirzadeh ${ }^{1}$ \\ ${ }^{1}$ Department of International Relations, Tarbiat Modares University, Tehran, Iran \\ Correspondence: Mohammad Hossein Jamshidi, Department of International Relations, Tarbiat Modares \\ University, Tehran, Iran. E-mail: Jamshidi@Mode
}

Received: April 20, 2017

doi:10.5539/jpl.v10n3p138
Accepted: April 27, $2017 \quad$ Online Published: June 1, 2017

URL: https://doi.org/10.5539/jpl.v10n3p138

\begin{abstract}
Sadr as a reference and genius of the great Shiite in the contemporary era of those who was proposed a comprehensive theory about the possibility, terms and conditions of the realization of revolution under the leadership of the school of Islam. So, he is one of scholars of religious revolution and its realization in the contemporary era. In this regard, by relying on theoretical foundations and pillars of historical traditions and human freedom, he reviews issue of the possibility of revolution and its necessity in contemporary era, and then by relying on factors such as school, conditions of time and preparation, in understanding of school and requirements, ability of leadership, determination, facilities and abilities, and also with a focus on organizations and party as a powerful tool, he expresses how to achieve religious revolution.
\end{abstract}

Keywords: Seyed Muhammad Baqir al-Sadr, revolution, religious revolution, tradition, liberty

\section{Introduction}

The phenomenon of the revolution and realization and necessity or lack of it is based on revolutionary theories and revolutionary theories have been proposed by prominent scholars and experts, as Marx and Marcuse in the West and in the East Jamaluddin Asadabad and Imam Khomeini that have been attempted for it. So, to understand the revolution, foremost awareness of these theories are the revolutionary theories which are often in addition to the theory of revolution; is essential, and this is particularly true about religious revolution or the revolution, a revolution of values based on religion and based on the ideology and worldview and value-driven perspectives.

Among all those in the religious revolution or Islamic Revolution that have theorized as decisive ideological, there are only a few that are known as "pillars". The basic pillars are as follows: 1) supreme leader of the Islamic Revolution Imam Khomeini 2) Martyr Sayyid Muhammad Baqir Sadr stepfather or intellectual father of the Islamic Revolution 3) Dr. Ali Shariati 4) Morteza Motahhari 5) Seyed Mohammad Hosseini Beheshti.

In fact, it could be cited from the five people as the five pillars of theoretical and theorist of the Islamic revolution in modern times. On the one hand, refers to the fundamental worldview of Islam, and on the other hand, ideas and even some of the other characters they have been role in providing theoretical solutions or expression of practical measures in line with the Islamic revolution in Iran, however, the role of these groups is very tangible and decisive; in particular, the great leader of the revolution, Imam Khomeini, had the leadership of the intellectual and practical leadership. After Imam Khomeini, among authorities, the elites and expert that have had role in terms of theoretical than others in the fields of Islamic Revolution, is martyr Sayyid Muhammad Baqir Sadr that K. Mojian has been expressed:

"Clearly comprehensive theory of social and political revolution has been promoted the establishment of an Islamic society, which in the case of Ayatollah Khomeini government was fulfilled" (K. Mojian; 2018: 20). One of the most important measures in connection is writing this valuable book al Yaqud Alhayat and submit it to the revolutionary nation of Iran.

In addition, he through valuable works such as Flsftna, Aqtsadna, Almdrs.h Islamiyah, and especially the "Aleslam QoyoutAlhayat" pay to play such a role; he has statements, writings, fatwas, declarations and actions in this area. So that the different contexts are Islamic revolutionary theory and the nature of its expression in the thoughts and opinions of Martyr Sadr confirmed his basic role and influence, but what is important here and can be investigated; is Islamic revolutionary theory and the nature of its expression in the thoughts and opinions of Martyr Sadr. To answer such questions, we studied the discussion on four major issues. 


\subsection{Socio-Political Traditions}

One of the key concepts in Shahid Sadr revolutionary theory is the concept of "socio-political tradition". This means that in this view, society, politics and history have many criterion, more precisely law is that lies at the heart of it. These laws are covered all fields of human life, especially in politics namely public and the universal arena of destiny (Jamshidi, 2007: 84-85). Therefore, one of the most important tasks of the scientists is the discovery of these laws and giving direction to people life based on them. Among characteristics of these laws is their relationship to the human will and freedom of action. So, in a sense, these laws can be considered "natural and human".

However, in view of Sadr, Quran is a book of guidance and leadership of human as the original text of Islam. Ratio of human issues such as movement, uprising, fight, politics and public administration, the socio-political and historical laws, on the expression of Sadr, "... there is discussion of laws of history, a strong relationship with Quran as guide, as a book that led to the light from the darkness of error." (Sadr; [AH], B., 51_52, [t]; B, Page 117...

The rules and regulations have been in the language of the Quran as "tradition" or "sign" and collectively the "traditions" and "revelations" that sometimes has been added in the name of God and entitled "tradition of God" or "words of God" has been mentioned. For example, in verse 137 From Surah Al-Imran has been written like this: And on this basis, special attention

"There have been examples before you. Journey in the land and see what was the fate of the liars" ( Sura 34: AL-ANAAM).

Sadr in interpretation of this verse from the Qur'an, writes: "Therefore, words of God are not converted, namely signs of promises throughout history cannot be changed." "Word" means a direct relationship between victory and fulfillment of its conditions ... this relationship is a historical tradition. "(Sadr; [AH] 64, [T]: 126_127).

In this expression, the words of tradition, traditions, word, words, "Verse" and "verses" have been used to express these rules and regulations. Divine customs are actually cause and effect relationships between natural phenomena, human and social. Therefore, due to three kinds of phenomena, historical traditions also are expressed in three ways: 1) Natural laws and traditions: that is governed on the relations between natural phenomena such as "boil water in 100 degrees." The traditions have aspects of "causal", therefore, humans will does not interfere in them and merely express the causal relationship between the phenomenon.

2) Human traditions (individual): laws that is governed on the individual human relationships such as "students succeed in the exam by studying". These traditions in addition to the causal aspect have also goal or ultimate aspects (the final cause), and are voluntarily and optionally, and the will of humans is contributed to them and is usually expressed as conditional sentence: "If you study well you can be successful in exam course."

3) Socio-political traditions (historical): there are regulations that are governed on the social and political relationships of human beings, like "realization of justice in society is followed stability of the state". These traditions have three aspects: the cause (efficient cause), purpose (final cause) and wave (effective cause). This means that in addition to voluntarily, a wave is generated that engulfed the community and is affected. They have usually the condition case, such as: "if you fear Allah, He will give you a criteria" (Al-Anfal: 29) or "Allah does not change what is in a nation unless they change what is in themselves" (Raed, 11). The topic of discussion here is third type of traditions that has social and social, political and historical aspects.

\subsection{Forms and Features "Divine Traditions' or Socio-Political Traditions}

Allameh Sadr cites generally three forms for divine traditions that are included: 1. form of conditional theorems; 2. form of current, certain and fulfilled theorems, 3. Form of orientations and innate tendencies.

He about the first type (conditional propositions) writes: " The first form of statements of historical traditions in the Quran is appeared in the appearance of conditional theorems, and between two phenomena or two sets of phenomena in the field of history (and politics) are contacted. Quran makes it reliant hard to each other this communication as a separate and legal relationship. So that he says that whenever condition is achieved, the realization of punishment is inevitable. "(Sadr; B [M]: 101, D: 163).

Like: "Allah does not change what is in a nation unless they change what is in themselves" (Raed, 11). This tradition is in the language of the conditional case, since its return is to the bond between the two types of change. 1. Change the nature and content of internal and external of people 2. Change in appearance and social and political foundations of the nation.

The second of divine traditions that are presented in the form of certain current theorems are related to natural laws. Like the earth revolves around the sun. On these theorems, human cannot be changed because like de facto 
has been realized. The important point is that such cases have nothing to do with the will of man and his social and political destiny, but many Western traditions with the human with the illusion of opposition to this idea were wrong that if these are non-modifiable, and is determined the course of human life, What remains another man's freedom? Therefore, some like Marxists turned the forces of history, and others said social traditions should be sacrificed human freedom.

The third type of traditions is expressed in the form of trends and man's natural attractions. They have external reality, and are for propel the man to the perfection, and they have originality, but they do not have decisiveness of first and second type of traditions, and therefore can be struggled with them. Of course playing with these traditions is detrimental to the individual and society, and various deviations will be followed and the result is weakness and degeneration or death. Some of these trends are included "the instinct of curiosity", "sexual orientation," "Natural need of men and women into two kinds of behavior in life" and "pious", etc, Shahid Sadr wrote about the Third Kind of the traditions:

"This trend should not be called a piece of credit legislation, but is the main attraction that was created to follow the path of human movement. Their roots lie in human nature and human construction depends on them."(Sadr, B. [M]: 114, D: 173).

Therefore, in view of Sadr, these are not from credit and legislative affairs, before it that are from the real matters and in evolution, and have root in the nature of owner of wisdom and authority, and therefore are the tendency, feelings, etc.

\section{Features of Divine Traditions and the Human Will}

Traditions features are included:

1) Traditions are fixed and immutable, and none of factors ranging from natural or synthetic factors, they are metamorphosed and do not change. It has been repeatedly emphasized in the Quran. For example: "You shall find no change in our way. (Isra ': 77)".

2) Traditions are impenetrable exceptions, citing the verse 214 of Surah Baqarah, Sadr wrote:

"... Allah attacks them because you hope for you is exceptional in traditions of history there. Do you have a taste of history about violates your laws? Therefore, help of God is near. But help of Allah has a way. Quran wants to say Not its undisciplined, not accidental the way to go ... it must be recognized traditions, history, the logic of given date should be reached with the help of God Almighty. "(Sadr, [M]: 64, T: 131).

Acquisition and generalization (Catholicity): Divine traditions are comprehensive, general and universal, and have a whole. In addition, they do not indicate without account relationship and blindly. Totality of rules is presented scientific character to them, and motivates humans that inducted and discovered, and their life path is changed and developed with their proper understanding.

"Popularity and universality of the laws gives scientific aspect because the most important advantage of scientific laws is that is inclusive and has universality." (Sadr; [M]: 75, T: 139)

Holy Traditions: have divine aspects. This subject goes back to the fact that man is dependent on the absolute ideal (God) and God realizes by the same laws and traditions, "will" and "wisdom" and "policy" in the world. Of course, this does not mean because phenomena are attributed to God, and follow no other links with the other phenomena and especially natural and physical phenomena as can be seen in the Christianity:

"When Christianity [today and distorted] is considered objective and the divine aspect for a historical event and wants to justify his divine. The person is free in all its actions and behaviors. Human is meaning and concept of "will". If the force "will" not in man, his discussion of release was considered unnecessary:

"Therefore, Human in addition to organic device and his soul equipped with a will and thus freedom is his favor, and is object of his love. Because "freedom" is interpreted as objective and scientific for willpower because the freedom for human is ensured that is owner of his will, and will be able to use in application of his goals. (Sadr; [z]: 21-22, and [it]: 48).

"Therefore, human in addition to members system and their souls is equipped with the will, and thus freedom is liked and respected it because "freedom" is objective and scientific interpretation of the power of will because freedom to humans is ensuring that is owner of the will and can make use of their wills in the application of its objectives. (Sadr; [g]: 21-22, and [it]: 48)

And the will is also obtained intelligence and human speech as the only rational and wise animal.

So according to the definition of Sadr's freedom is included: 
"The possibility and ability to use and objective and scientific interpret will be to achieve his transcendental goals, and it rejects any association with others for the events. Once all relations and links with objects and other events will unbind that divine bond catch them all. And whereas the Qur'an, is not given divine color to historical event that is stopped it of other relationships, and make related directly to the God. Quran is not considered relationship with God instead relation of cause and effect. Quran is accepted relationships between historical events of this world, but he says the relationship between historical events is interpretation of the wisdom of God, good policy and his cum in the building in the world and in the arena of historical events (Sadr, 1991[Q]: 142_143)

The role of human will and freedom, traditions and social laws of Quran is emphasized that social and historical traditions, the second and third, are passed of subordinate's human, why? because those that are related to the political destiny of human beings, because all of conditional cases are fulfilled, and being conditional depends on the will of human beings. It can be gathered historical traditions with the will and human freedom. Basically, the expression of social and political rules as conditional is the biggest reason on being free of the human beings and his will power to choose the way. For example, three conditional theorems of divine traditions that have political and social aspect that are presented here:

A) The relationship between human transformation (revolution) and the divine transformation (victory): "Allah does not change what is in a nation unless they change what is in themselves" (Raad, 11).

B) The relationship between "persevere in righteousness and piety" and "breadth and social welfare" (Jinn: 16).

C) The relationship between cruelty and destruction of the oppressors caused by oppression. (Kahf: 59)

Sadr said after describing of three relationships:

"See how the historical traditions are not that human, but all under the control of God in human life any desired changes to deposit, and whenever people follow the true way, GOD give him a good life. These are positive. For human freedom and choice has been shown its free decision. "(SADR no to (d), 84)

\section{Human Freedom}

The concept of "freedom" is also one of the fundamental bases in the Sadr political thought. The first point that is discussed here, is freedom fresh and new phenomenon and as a human achievement, or is a subject for a man who has been since the creation of mankind? From Sadr view, "freedom" of human beings has a special emotional connection because human by hearing it, trying to get feel special. The human emotional connection with the freedom is indicated that is mankind freedom, and has been introduced consistent with the birth and His creation on earth. Therefore, human freedom is rooted in the foundation of his existence and is non-disintegration part and parcel of his existence: "It's an emotional connection that man feels in him with freedom, a new phenomenon is not in the human history. As among are not gains a life of in the capitalist and communist societies today, and misuse of some modern civilizations is not indicative of a deep connection with the human soul is the concept of freedom that is indicative of a deep connection with the human soul that emotional connection between man and the freedom is deviated, that throughout the history of humanity, every crack, is appeared to have made. "(Sadr B. [of]: 21, and B. [it]: 48).

The emotional connection between human and freedom is indicated that human is field to free and release rather than look outside of them for the freedom. In terms of Sadr what is "free" in this sense, a positive sense of freedom because freedom is to realize one thing that is will. Freedom has the positive sense, and is from the necessities of human life. As Imam Sadiq (AS) says:

If someone does not have the five characters, he cannot take much interest from his life. 1. to fulfill that promise, 2. Policy,3-Bashfulness, 4- good mood, 5. The last of these is the freedom that comprehensive all of them.)

Negative concept of freedom means "freedom from the domination of others" which is more common in the West, is also, is also hidden in positive sense, and has secondary side. If freedom of the concept of "realization of human will" is perceived, inevitably others will not have dominance. Since activity and expansion of individual is understood regarding the obstacles and limitations that are faced by others. Therefore, freedom is found negative and deterrence aspect in the West, in the utilitarian of liberalism of freedom to "do no harm".

In addition, speaks of two kinds of freedom: "natural liberty" and "freedom of association". Natural liberty is same realization of the will that nature and existence is given to the man, and is part of his nature.

Natural liberty has been "essential element" of human nature, is a basic phenomenon in which all living creatures are with different ratios, according to range of their life in it. For this reason, the share of man's freedom has been over the share of other organisms. "(Sadr, 1979: 281, and 1360: 1/306) 
In expression of Sadr, this freedom is part of the nature and human nature, and the expression of his will power and without it, humanity, the term is meaningless (Sadr, 1979: 282 and 1360: 308)

Freedom from Sadr view, sometimes the realization by the will under the command of wisdom is taken practical form, and has also negative dimension. But not as those who have been raised in the West, but to the more fundamental concept, means freedom from the dominance of negative factors within (greater jihad) and liberation from the domination of all constraints and external sections. The negative aspect of freedom is highly valued for Islam. For this sense, freedom in Islam represents a comprehensive movement for human freedom from the domination of others Freedom from bondage chains. That it was caught throughout history. "(Sadr, 1979: 109 and 1970: 108)

Basically, the concept of the meaning of freedom in Islam is positive and negative aspects in the implementation; on the contrary freedom in the West, that is mostly taken in the sense of negative aspect and in the realization of positive aspect. Therefore, according to Martyr Sadr, this practical aspect of freedom with the positive aspect of freedom is irrelevant which was raised in the West. (Sadr, 1979: 109, B [a]: 105)

Also, in the view of Sadr, "social freedom has also a factual content that he has considered it as "Intrinsic and social freedom" that it: "is the power that human is achieved for acting to the certain action. The purpose of this power is that society is provided all the means and conditions that are necessary for participation in it "(Sadr, 1979: $283 ; 1982: 1 / 310$ )

This kind of freedom is the result of natural liberty, but social freedom also has an appearance that is called it "formal and social form" upon which person is apparently and "officially" free in society, however, it should be considered this freedom in his heart is devoid of any truth. Although it is not always empty. Freedom in Western liberalism is usually like this (Sadr, 1979. 293-283; 1982: (1/320_310).

The first point is discussed here. The first point to be discussed here whether freedom a new phenomenon and is part of human achievement? In the view of sadr, man with "Freedom" has a special emotional connection. The human emotional connection with freedom is indicated that freedom is human subject and in line with the Earth's birth and his creation has been rooted in the foundation of his existence, and is an integral part of his existence:

"This emotional connection, that man feels his freedom, is not a new phenomenon in human history. As is not also among gains a life in capitalist and communist societies today, and misuse of some of today's civilization from this concept that the emotional connection between man and freedom has been led to astray that is represented deep connection with the concept of freedom with the human soul that throughout history of humanity, by every crack is appeared. "(Sadr B. [of]: 21, and B. [it]: 48)

This emotional connection between freedom and human is indicated that human is right of make free and get free rather than look for freedom outside of them. In terms of Sadr what "freedom" means in this sense is for the realization of the will. So, freedom has basically positive content, and is the necessities of life. As Imam Sadiq (AS) says:

"If someone has five characteristics not on their life will be a lot of interest. 1. Faithfulness to a promise, 2. Prudence, Bashfulness 3-, 4- good mood, 5. The last of these is freedom of all of them. "(Hurr Ameli, 1409: $20 / 51$ which is more common in the West also lies in the positive sense esteem and sub-aspects, it lies also in the positive sense, and has the secondary side because if freedom is understood as the concept of "realization of human will", inevitably others will not have dominance at this. In the West is understandable since the expansion and activity of individual due to the obstacles and limitations that are faced by others, and inhibition is taken.

In addition, Sadr speaks of two kinds of freedom: "natural liberty" and "social liberty", and "natural liberty" has been "intrinsic element "of human nature, is basic phenomena on which all living organisms with different ratios, according to average of their lives are participated. For this reason, the share of man of the freedom has been over the share of other organisms."(Sadr; 1979: 281, and 1360: 1/306) and" Without it, humanity is the meaningless term."(Sadr, 1979: 282 and 1360: 308)

Imam Ali (AS) says about freedom of human nature:

"Do not be other's servant while God created you free" (Imam Ali, B: 929 / N 31).

Freedom in the view of Sadr to the time of realization, by keeping will under the rule of intellect is practically taken, and has a negative side as well. But not in the sense have been raised in the West, but also to the fundamental concept is that liberation from the domination of negative factors within (jihad) and liberation from the domination of all external constraints.

"... Freedom in Islam represents a comprehensive movement for human freedom from the domination of others 
and freedom from bondage chains. That was caught up throughout the history. "(Sadr, 1979: 109 and 1358: 108)

Also in the view of Sadr "social freedom also has a real content which he is known "Social and intrinsic freedom" which it: is a power that is obtained by men of society to take certain action. The purpose of this power is that society is provided all the means and conditions for participation in the action that is necessary. "(Sadr, 1979: 283 ; 1360: 1/310)

This type of freedom is caused by natural freedom, but social freedom also has the appearance that is called "formal social freedom," according to which the person is apparently and "officially" in a free society.

However, it should be considered this freedom in its heart is devoid of any truth. Although it is not always empty. Western liberalism tends usually to be like this. (Sadr, 1979. 293-283; 1360: (1/320_310)

In addition, in view of advent of Islam based on natural liberty is not considered the meaning of formal and apparent freedom that the West has always called it, but the meaning is far broader and deeper than it is considered and it is called "a major revolution in human freedom" (al-Sadr, [of] 23 and [it]: 50-49).

And the concept of freedom with the concept of freedom in liberalism that only means absolute freedom with the stipulation of do no harm to others has significant difference. Even with the Hegelian concept of freedom was quite foreign. For Hegel is extending, however, limits scope to matters of public order and public interest is not opposed, but its task is adjustment of liberal freedom, in a way that is consistent with the philosophy of Hegel. On the other hand, his attention to inner freedom of the human will is dominated by historical determinism and absolute spirit of God Orion of empty history and that he thinks:

"Freedom is not habitual obedience to the law and practice is not based on moral conscience and critical acceptance" (Plamnatz, B: 157) but studying is not based on moral conscience and critical admission "(Plamnatz, B: 157)

How is compatible with algebraic move of history? However, Hegel is rejected Philosophy of Right is the ability to do something that is good for us »(Hegel; 27) which we on our desire form an ethical system. How can be moral order and being free will covered inherent and natural dimensions of human freedom, due to the:

"The only kind of freedom" (in the country), which may arbitrarily be limited is originated of specific needs. "(Tabatabai, 12_10)

Apparently, such an interpretation of freedom, the negation of freedom will be followed because unity "necessity" with "freedom" led to the destruction of freedom.

According to Sadr, one of the main differences with the concept of freedom in Islam and concept of freedom in the West is that:

"Freedom result of West civilization for human begins of freedom for human, and ends in various forms of slavery and being imprisoned. In the event that freedom in Islam, first begins slavery and servitude and devotion to the God, and then ends to the freedom and release from slavery and worldly servitude (Sadr [of]: 24_23 and [it]: 51).

In the view of Shahid freedom in Islam is realized in three stages:

1) Inner freedom stage (emotional and mental freedom), at this stage, man by admission of servitude begin the absolute ideal of transformation on their content:

"Islam begins human freedom from change and transformation in the content of humans, and entails that by it, is achieved freedom of spiritual truth, and can be always kept humanity and their character in the path of life "(Sadr, [of] 24 and [it] 52_51)

2) External freedom stage (freedom in actions, behavior, etc.); considering that the acts and actions of man are the result and expression of soul and spirit, can with the freedom of his soul to fulfill his will, according to their wisdom and inner freedom.

3) Social freedom: Human is free in the owner of the will and powerful within the community.

\section{Possibility and Necessity of Revolution}

According to three basic introductions to the supremacy, "existence of political and social traditions governing the universe", "freedom" and "human will" the transformation of the individual and society from the view of Sadr, it is not only possible, but is necessary. It encompasses all aspects of individual and social life. In addition, the evolution of the world is a dynamic and continuous movement that has numerous ups and downs, although the movement of societies and human beings is as a whole toward progress, but in different sections and positions can 
be made degeneration, weakness and recession.

On the other hand, evolution in individual and social life is not only of material and experimental, but has spiritual and moral perfection and development of spiritual and intellectual well. Although it is possible that society is one of the aspects of the development, growth and progress in other aspects of the evolution step and goes to the degeneration and weakness. Sadr wrote:

"Human life will not be in decline and stagnation, but also is facing to the evolution, and this evolution in all aspects of human life is flowing and the relations and coexistence of human and material aspects of the thoughts and insights in material aspects, relations, coexistence of humans, the thoughts and insights. And this evolution and move is that sometimes life and its manifestations are drawn on the development and well-being, and sometimes to decadence and backwardness. "(Sadr, 1407 E: 53, 1359; [1]: 59)

Also in the view of Sadr, evolution and transformation and changes are performed in community and individual that has the major two dimensions:

1) Moving towards optimization, development and desirability.

2) Move toward purification of soul and thoughts of excellence (al-Sadr, 1407: 53 of 1359; [the]: 9)

Indeed, the two dimensions under the title of "lesser jihad" and "greater jihad" in Islamic tradition has been proposed. Victory on the evolution of lesser jihad, it tends to bring a better life to material prosperity and victory on the evolution of "greater Jihad, purity, self-insight, self-esteem and to become godly man and society is followed.

Evolution and development have general principles that are included:

1) There is school and ideology of human beings that is replied correct answers to the demands of human nature, and based on rationalism, knowledge and correct insight towards existence is based.

2) Facilities and proper requirements, even though no move without requirements is performed possible.

3) Free human being so that he can choose and decide.

Moving and going forward to the creation of man to the changes in their environment.

Expressed by Sadr, "revolution" that is necessary changes in certain situations that are required four pillars. According to the preceding discussion, at the time of Shahid Sadr, there is an efficient and capable "School and ideology" such as Islam, even though school is needed to correct recognize. Divine customs are represented circumstances and accessories that by recognizing them, man and society can realize the possibilities and requirements and then act. Also, free human beings have been trained in Islamic school will have the potential ability to choose and decide. Therefore, the provision of three pillars, the possibility of "revolution" as the possibility of "evolution" is something definite. But the revolution is necessary that is occurred under certain conditions, and man to achieve it should be relied on three sections. Three sections consistently can be created favorable evolution and changes that are included:

1) Wisdom and knowledge that is explained clarification and explanation of the school, traditions and possibilities.

2) Feelings, emotions gushing and deep spiritual desires, because every move must be rooted in the human soul.

3) Action and movement that will be manifested mobilizing the intellectual and academic of the human resources, we call set of the three sections as revolution triangle.

Wisdom, thought and science

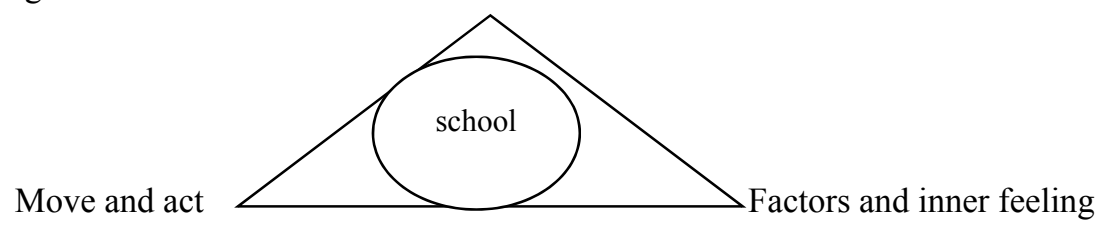

In the view of Sadr, "Islamic school" has been raised the three sections, and is dominated on them (Sadr, 147.H 27-28 AND 1981 ®29-30) (revolution pyramid).

\section{The Concept and the Necessity of Revolution}

The word of revolution in Farsi is equivalent of (Revolution)in English which is originally meant "away" and 
"circulation" in terms of science of astronomy and for the first time in the seventeenth century as a political term meaning " circulation instead of first " and "return to order that has been predetermined." And finally in the sense of "outright overthrowing of the government of any country or state, and replacing ruler or a new government through violent" (Ali Babaei, 1991: 2 / 36-34 and Arendt: 57) was used. "Revolutionary" is originally Arabic word and from the origin of "heart". (Malhuf: 648)

The case of other human movements is in the same way. For example, to create "equality in society" should first offer school to correct insight about them. Then concept of equality becomes clear through reason, thought and guidance of school, its dimensions are explained considering the circumstances of the time, and finally, the community is known about it, but school was acknowledged it, and is also known in the community, and become widely accepted "equality" was not made. Therefore, in the next step, the belief in this concept should be created so that opens within and in human emotion, and become to the soul and spirit. When "the spirit of equality" came in hearts, and was a component of internal emotions of people, and this feeling was created that turn to move, mobilization and action to create "equality in society". In all the stages, there is also belief in "equality in society" caused by ideological worldview, and is light of the way. Evolution, advancement and revolution in society can be realized in a similar way. Means with the coordination of three elements (intellect, emotion and action) of human will, the school and correct insight about evolution, advancement and revolution, they are realized in the community.

So, revolution has been in means of upside down or reverse upside down as well as up, transform, rotate, change and. In the Holy Quran verses such as 144 and 147 Aleemran has been also the same meanings of the revolution, is not a common today means, finding new and new face. In Arabic language against words of revolution Fars and Revolution is used "Al-Thawra" that word means "revolution," "Uprising," rebellion "," chaos ", and" rogue "states. Also, famous family of "Sar," or "Thaer" which has been usually means revolutionary, rebel, revolt and. In the shrine of Imam Hussein (AS) is inserted:

"Is not seeking vengeance on one's murderer stem from grudge and hatred? Isn't the heart of a believer purified of hatred and grudge?" (Qomi, Ziarat Ashoura).

Shahid Sadr in the discussion of all kinds of invitation or movement is speaking from two kinds of invitation or two types of movement:

1) Invitation or reform movements or "reformist"

2) Invitations or revolutionary movements or the same a "revolution."

3) He says in the corrective invitation:

"The corrective invitation aimed at rehabilitation of certain sections from society and in terms of their practical activities from other aspects of the fundamental corrupt of social reality is condoning that is the foundation of the current situation."(Sadr, B. to c: 27)

A) Restoration of a certain section from society;

B) Ignoring other aspects of social reality;

C) The principles and basic and fundamental foundations are ignored, so

D) Aims to maintain the status quo.

Sadr, in the case of the revolution "Alsvrh ... 'or revolutionary movement wrote:

1) invitations or reform movements or "reformist"

2) invitations or revolutionary movement or a "revolution."

He in the corrective invitations says:

"But revolutionary movement whereas of the fact that it is the nation grapple that has a clear conception and deep impression, delivery is not absolutely the current atmosphere and conditions and because this atmosphere to the principles and his intellectual are found conflict and violence, and is hardly achieved fundamental change and deep transformation. And in this way, with the help of richness of mission bears, give the promise of new life and fertility and richness ideological school of thought based upon that, a life that has been sent to last criteria to the cemetery's history, and is organized in the new and revolutionary design of personal and social life and government operations. (Top; B; [H]: 27)

So, the characteristics of a revolutionary movement are included:

1) is conscious move, 
2) the movement is against the status quo,

3) is a tough, hard-hitting move (volatile)

4) is followed the deep transformation and fundamental changes,

5) transformation is to create a "new life",

6) This movement is based on the school,

7) In this movement is skipped last criteria and principles.

According to what is presented here, as well as other Sadr's works can be expressed it as stating the revolution.

"Revolution is included stubbornly movement, and is based on the certain school principles that is governed by clear conception of existing realities for deep and fundamental change and transformation in all dimensions of human life, social and political norms, principles and fundamental values "(Al-Husseini, 1989: 361_362).

What is this definition of definition of revolution theorists such as Huntington (Huntington; 1976: 264) Arendt (Arent; 1063: 21), and so is distinguished that has the two basic points:

One is that revolution is done with the clear conception of existing realities, first, the community becomes aware of its condition, and coordination of atmosphere with the ideals and goals recognized, and is based on such diagnosis that is taken place the revolution. The second point is that the revolution is done based on certain philosophical school. In fact, the 'school' is intellectual mother of the revolution.

From the viewpoint of Sadr, prophets have come to realize of revolution in infected and oppressive society, and there is not a separation between revolution and divine mission. Because the Prophets have come to open bonds of hands and feet of people and ridding them of slavery and oppression, and this is followed a fundamental change."On this basis, we believe that the true revolutionary cannot be separated by no means of revelation and prophecy and along which in human life, as prophecy and divine mission are not isolated of social revolution against exploitation and outbreaks. (Sadr, 1399 [H]: 41, 1359 (i): 36) In another place he wrote:

" The Islamic perspective on mission is a gushing and revolutionary thought" (Sadr, 1407: 75; 1981 [in]: 86).

Now, it should be observed Shahid Sadr is following the revolution or reformation. In this case, he consider basis on the condition that Islam is confronted. According to him, if Islam is the underlying platform and the major social life system, then the invitation of Islam will be automatically modified. Sadr believes by the end of World War I more or less such a situation has been favorable for Muslim societies, but since then that Islam lost its central database, it is evident the necessity of revolution. Therefore, from the perspective of the early twentieth century and after that period is that has become apparent the need for a revolution in Islamic societies. He wrote about moving "the party of Islamic invitation ":

".. That is why our invitation has been taken the revolutionary line to rescue the nation from lost and distracted of the current situation, and in this way, the God order has been accepted that said: "Believers! Shall I direct you to a commerce (Sadr; [H]: 3, Al-Hussein; 1984: 363)

And in another place, he writes:

"Now Muslims are in the fight against the widespread social backwardness living ... but after all the efforts that is performed good and evil except the final will not find a way to win," Revolution in the light of Islam. "(Sadr; $1981 ; 180)$

Sadr also in the books "Resaltena" and "Almahneh" and placing an emphasis on the necessity of revolution in the current situation are explored. He also confirms the intellectual and practical comprehensive Islamic Revolution of Iran and the writing of the valuable book "Al-Hayat al-Islam Yaqud" and submit it to the revolutionary people of Iran, part of which is a draft for constitution of the Islamic Republic of Iran. "Allah does not change what is in a nation unless they change what is in themselves." (Raad: 11) It is to achieve and carry it to victory the revolution began and the issue of the role of man and the necessity of revolution.

\section{How to Realize the Revolution}

Mentioned earlier that from the viewpoint of Sadr "revolution" is a phenomenon that in the certain situations, is necessary and indispensable, but that view is completely different in the eyes of Marxists. (Sadr, 1408 of the 242, 1360 [No.]: 253) In terms of Sadr, Marxist consider revolution as the only way to political power or materials processing, which is achieved through political power. And therefore, to express their opinion with the philosophical leap is justified it. While the revolution may be a phenomenon that is felt necessary under certain conditions and with the understanding of those conditions, and after realizing its necessity, people make voluntarily and knowingly revolution, so revolution is collective action based on knowledge and determination to reject the Marxist theory. He writes: 
"Considering the fact that Marxism wants the" social revolution "of mutation in nature is inferred compounds such as water, or the samples in chemical compounds found, it must be concluded will bring a photo, under "social revolution" as well as heat water with external factors (and not inside and dialectical) are interpreted, these are external factors that by completion them, the revolution is realized and with the lack of completion, completion does not occur, and therefore this law appears to me, just as water can be kept away from external factors and heaters can also society be revolutionary causes. "(Sadr, 1408: 246 and (p): 456)

In general, important factors that are effective in the revolutionizing are included:

\section{A) School factor}

From the perspective of Sadr, the primary factor for each revolution 'school' is. School which is competent and has clear aims and objectives of human life and offer excellent examples of moving towards a revolution:

"The main factor for movement of a nation, any nation that is, is existence of school of rich and deserves origin by which its goals and objectives are measured, and accordingly has been provided excellent examples, and has been presented orientation to community life. And within a radius its perfection of confidence that has the mission, and with respect to the objectives and purposes of the samples and a positive ideology and moral character is inspired by the march of the revolution. "(Sadr, 1407 E: 17 and 1360 [R] 17_18)

But existence of a school alone cannot lead to revolution, but the need for proper understanding of it and in the result of faith in its principles are presented. He wrote in the expression of school and its characteristics:

"We mean the departure and competent of school: the occurrence of such a school, and appropriate origin, second, the correct interpretation of that school community; and Thirdly, a school is faith. When these three fundamental principles among the nations came together and the nation has a school and proximal to understand it, and they have faith, you will be able to achieve a real movement and changes in the life of the system created by that school. "(Sadr, 1407 E: 17)

\section{B) Operating time, conditions and preparation}

Another factor is the realization of the revolution and the demands of the time it is debatable in several aspects: The first-dimension conditions and requirements is related to social and political atmosphere prevailing in the city; for example, when the state must leave the community of Basis of Justice and injustice, and to hedonism and not walk away from people, is not revolution possible. Sadr in the expression of 'paradox, arrogant and weak "," weak and strength "or human-human paradox are presented. Risk revolution is not "class contradictions" which is constituted only a part of it. (Sadr [M]: 12_13)

The second dimension is the need to prepare people, this means that if people do not understand the current situation and preparation to get rid of such a situation. The revolution will not be possible. This is about divine revolutions such as "revolution of Imam Mahdi (aj)" is true:

"... in the circumstances of the movement's victory that is included mean of preparation community, God's plan is that it should be natural and normal condition is usually the result of a stylist is, each nation must be ready to change and alteration finds. "(Sadr 1398: c [95-96 and 1398 [A]: 75-76)

The third-dimension issue is related to external factors. Factors that may have a role in the advancing the revolution and sometimes as a barrier against the revolutionary movement arise. Sadr wrote:

"... By comparison can the revolution led by Lenin in Russia, give a small example in which factors such as World War I, the precariousness of the tsarist empire, ... and create an environment conducive to change and more specific factors, such as Lenin stay healthy travel who led Russia and the revolution, was dependent. "(Sadr [the]: 76_77)

In general, Sadr view: "The victory of the revolution and social activities, in a series depends on external circumstances without providing them revolutionary situation cannot be reached your goal. (Ibid.)

Sadr insists that the revolution is not possible to factors such as divine providence or accident attributed luck and ... because they are contrary to the divine customs and umbilical human will. Therefore, the "human will" and "decision and the rise them" in the revolution is concerned. Since revolution has "voluntary action" should be realized the "will" and "movement" on owner of motion. (Haeri, 1407: 151_153).

"Of course, if the providence of the Lord is related. It can also be incredibly created good atmosphere and social preparation [mixture] create, but is against the tradition of right creation. His human creation to try and develop infrastructure, because human evolution depends on this quiz, and the requirement of implementing the program is to test the readiness of people to change and transformation positions are available. Not by compulsion of God ... "(Ibid.) But he rejects the influence of" the help of God, "' divine assistance "and" prayer "is not because 
they do not conflict with the advancement movement. (Ibid: 100)

C) Leadership factor

The third factor for the realization of revolution is leadership. Leader has been veterans and in character "Tazhieh" and intellectual power and spiritual power that can dominate a society that wants to transform spiritually.

"The large size of its intellectual thought that the woman the implementation of the development across the human world is a world that wants to alter its size that is larger." (Ibid: 51_52) He talked about the revolution of Imam Mahdi (AS) wrote:

\section{D) Other Factors}

In addition to the above factors, factor "tool" and "possibility" in both beginning of the revolution and the realization of it and achieve victory is essential. This factor has both "human" and "inhuman". In the human 'reason', according to nature "," experience "(Sadr, main 1407; 73_619," proper application emotions "," faith in the revolution "," Hope "," spirituality and morality "(ibid: 31 21), "unity and unity", "intellectual growth" and "social consciousness" and so it is important and in inhumane instrument, equipment, facilities, material in which is determined according to the circumstances of the time, is desired. One of these tools in Sadr's view is existence of the "establishment" and "party".

"In this regard without being encounter of legal obstacle, we can put on the name of the party and the movement and organization, because we are the party of Allah, Ansar al-Islam and his companions. In the social domain and call for movement and activity in the context of the way we act organization. At all times, our practice are of "inviting" and "ourselves" "inviter" we ". (Al-Husseini, 365_65)

In the Sadr view, creating the party is "legitimate" and "useful." About the legitimacy of these organizations, Sadr on the factors such as the need for "publishing and advertising concepts and precepts of Islam 'and the' transformation of society based on Islamic principles" and is stressed. Therefore believes in which for the realization of these objectives can be used of the desirable and appropriate to the circumstances of the time of any way in which would not be required "an act of unlawful and immoral," and party in our time is the best means of achieving the desired objectives:

"In the credibility and legitimacy of organizational methods to promote and strengthen Islam cannot be questioned or given the possibility of sanctity of the legal prohibition. Nation which has target to invite to goodness, enjoining good and forbidding wrong why cannot be formed organizations and associations. Structural and integrated identity and activities are used effectively with a greater return on the way. (Ibid.)

Sadr comment about the formation of "party" to the modern concept of Islam as a tool of revolution and promote a political agenda is so overwhelming that it is raised:

"Of course, if the Prophet (PBUH) lived in our time due to his wisdom, advertising methods, information and appropriate organization of contemporary era was employed. And the fact that the invitation of the Prophet (PBUH) by way of "organizing a" has not been alien. Indeed, for the convergence of attempts to Islam is done, integrate and coordinate them, and adopt more productive and more fruitful way to create a legitimate organization is not only in our time, but as change and mobilizing society in the way of Allah against organized unbelievers and is subject to it. It is obligatory. "(Ibid: $346 \mathrm{Sadr}$; (h): 9)

Also in his view, the usefulness of this organization has been experienced in the contemporary era, and circumstances of our time show that:

"The form and organization is successful way of social changes and justification and its tendency to goodness or evil and corruption." (Al-Husseini: 366, Sadr (H): 9)

But In terms of Sadr, what separates non-Islamic party of parties. It is an essential difference. This is essential because:

"Achievers go forward in the Islamic organizations in line with the mission of "Allah" nor treatise on" human. " is followed God, not from others, and their reward from God are not human beings. "(Al-Husseini: 266, Sadr (H): 9)

In terms of Sadr, the observance of "party discipline" is also obligatory, and such a requirement is based on three principles: «First, legal contract or an oath that has been taken member of the organization for commitment to discipline in accordance with the interests of the invitation, and in terms of jurisprudential, the person required to comply with the instructions. Unless, the member after topic detection with firmness and determination is done in 
respect of the implementation, second: ... fulfill all the aspirations and goals of the Islamic holy in the area of social life are dependent on collective and organized action and based on wise planning, and return any organizational work depends on the organizational discipline...

Third, apply the rule of the jurisprudent qualifications about the necessity of organizational obedience. (Al-Husseini: 366, top (H): 9)

Sadr is also emphasized on the necessity of prosecution "The clear purpose based on" the principle of purpose and the commitment of party members which requires avoiding maverick invited and observing its own responsibilities and their specific responsibilities. In addition, the party to realize their aims in particular to establish an Islamic state should take four steps:

1) Step of change in thinking, preparation and development of committed forces and fighters or cultural stage, "intellectual revolution".

2) Stage of achievement of power and the establishment of Islamic rule.

3) stage achievement of power and the establishment of Islamic rule.

4) stage surveillance, continuation of the revolution and the strict implementation of Islamic law.

Sadr has been emphasized according to the conditions of its time on two stages. He writes: "Major trends and genuine process..., and secondly to the political jihad. "(Sadr (H): 25)

\section{Conclusion}

In examining the phenomenon of revolution in terms of methodology of knowledge, two methods and the overall style are remarkable: posteriori method or data-based methods and historical investigations and sociological. In this way, the revolution is analyzed and assessed after the occurrence an event that at some point of human history has occurred. More researchers of revolution have explained and analyzed from this perspective, and with this technique which can be pointed to "Skocpol," or "Brinton".

The second way in explaining the research and revolutions is posteriori method. According to which researcher as a theorist and philosopher is considered revolution phenomenon as a humanitarian and political issue, and survey research about necessity and what it is. Martyr Muhammad Baqir al-Sadr is one of the second group theorists. His centrality of his theory is formed Religious revolution and the quiddity. So he considers revolution based on religion as historical and sociological problem, but as a matter of religious philosophical that is occurred by providing special circumstances -means emergence of the crisis in society and in disturbance of the balance of its political, social and cultural system, but realization of religious revolution is taken place in addition to reliance on a religious school or right religion - in his view of Islam in the contemporary era, it is depended on a basic and very important factor, and it is the will of man, the sense that religious revolution is not birth of date and conditions, but is product and function of the human will in dramatic circumstances based on divine revelation. The voluntary occurrence, religious revolution like any other revolution, is required elements such as knowledge, attitude to school and its knowledge, leadership and facilities, and can be seen will as a fundamental pillar and linking of these elements.

In his view, revolution has been considered to this means in Islam school, and its necessity has been confirmed. Accordingly, Islam is considered permissible occurrence of revolution in the critical condition that is not possible to regulate the affairs with the reforms and superstructure and sectional measures, and has noticed how and the ways of providing it in the desirable and worthy form.

\section{References}

Abdul Baqi, Mohammad Fouad, 1364 AH, Al Moajam Almofahrs Lalfaz Alqrn Karim, Cairo, Press Darolketab Almobsrieh.

Al-Husseini, M. (1989). Alshhid El-Sayed Imam Mohammad Baqir Sadr, Beirut Darolfrat, first printing.

ALI Babaee, G. (1991). Dictionary of Political Sciences, Tehran, locked in a second edition.

Ameli, S. H. (1409 AH). Vasayel shiie, Qom, al-Bayt Institute, 1409.

Arendt, H. (1965). On Revolution. New York, Viking press.

Arendt, H. (1983). revolution, translation by Ezatollah Foulad vand. Tehran, Kharazmi.

Harayr, D. (1988). Islamic movements in the Arab world, translated by Hamid Ahmadi. Tehran, Kayhan, First printing.

Hosseini, A. (1984). Hossein's uprising true face in the mirror of historical documents, translated by Ali Alavi, 
Tehran: Badr.

Huntrington, S. P. (1976). Politcal order in changing societies. Massuchusetes, yale university press.

Jalal ad-Din Mohammad Balkhi. (1993). Masnavi Maenavi, correction by Nicholson, Tehran, B, Third Edition, p. 863.

Jamshidi, M. P. (1999). Shahid Rabeh's political thought, Imam Sayyed Muhammad Baqir al-Sadr, Tehran: Institute for itical and International Studies of the Ministry of Foreign Affairs, first printing.

Maalouf, Lewis, Almonjd FI Allghh and ALALAM, Beirut, Darolshrq, published 13.

Majlesi, MB (1404) e.) Bihar al-Anwar, Beirut: Institute Alvafa.

Nahjolbalagha collected by Seyyed Razi, translation: Syed Faiz Ali Naqi al-Islam, Tehra, Faiz, B.

Plamnatez, J. (n.d.). political and social philosophy of Hegel, translated by Hussein Bashirieh. Tehran, Nay publishing.

Qomi, Sheikh Abbas, Jinan, Tehran, Forever various editions.

Sadr, S. M. B. (n.d.), freedom in the Quran (Appendix of Shiite leaders in the reconstruction of society) Translation Hadi Ansari. Tehran, Roozbeh.

Tabatabaei, S. J. (1990). income philosophical history of political thought in Iran (2nd ed.). Tehran, Islamic Culture Publications Office.

The Holy Quran.

\section{Copyrights}

Copyright for this article is retained by the author(s), with first publication rights granted to the journal.

This is an open-access article distributed under the terms and conditions of the Creative Commons Attribution license (http://creativecommons.org/licenses/by/4.0/). 